\title{
An Empirical Study on Effects of US Treasury Futures Market on the KTB Futures Market and Its Information Transfer Effect - Mainly after the Global Financial Crisis
}

\author{
Kim Sung-Hyun ${ }^{1} \&$ Park Sang-Bum ${ }^{2}$ \\ ${ }^{1} \mathrm{PhD}$ Candidate, School of Business, Korea Aerospace University, Gyeonggi-do, Korea \\ ${ }^{2}$ Professor of Finance, School of Business, Korea Aerospace University, Gyeonggi-do, Korea \\ Correspondence: Park Sang-Bum, Professor of Finance, School of Business, Korea Aerospace University, \\ Gyeonggi-do, Korea. E-mail: psb@kau.ac.kr
}

Received: October 8, 2015

Accepted: November 9, $2015 \quad$ Online Published: November 25, 2015

doi:10.5539/ijef.v7n12p262

URL: http://dx.doi.org/10.5539/ijef.v7n12p262

\begin{abstract}
Since the Global Financial Crisis in 2008, funds have been moved to safe assets from previously preferred risky assets on a global basis. Moreover, the financial crisis ignited in the U.S.A. led to strong quantitative easing policies, which played a major variable in the monetary policies of the major countries. So, the US treasury yield rates and Korean counterpart have showed signs of being synchronized. On the other hand, foreigners' investments on Korean bonds became accelerated; the amount invested to Korean treasury by foreigners as well as their influence in the Korean treasury market has been expanded. Particularly, investment on the 10 year treasury bonds has increased, which spread influence of the Korean treasury market. In this regard, the study analyzed effects of the US treasury market on Korean counterpart. In order to analyze the volatility transfer effects from US treasury market to the KTB future market, in consideration of the synchronized maturity dates of the treasury and the officially announced prices, data on US 10 year treasury futures index and Korean 10 year treasury futures index . GARCH model was used for empirical analysis. Effects of the daily volatility and direction of US 10 year treasury futures index on the Korean counterpart was analyzed. Through the analysis, it was confirmed that information was transferred to the yield of Korean 10 year treasury futures index from the US counterpart. The study will be able to help establish more rational and efficient strategy for bond investment and operation.
\end{abstract}

Keywords: KTB 10 year futures, global financial crisis, US treasury futures index

\section{Introduction}

\subsection{Background of the Study}

To respond to the market volatility in the bond markets, national treasury futures are widely used as a substitute for government bonds as well as a mean for hedge. Korean treasury-bond futures are futures for Korean Government bonds with maturities in three or ten years which are traded in the derivatives market of Korea Stock Exchange. As Korean government bond market became activated in late 1990s, followed by Korean treasury-bond futures, futures with a maturity in three years have been listed since September 29, 1999, followed by those with a maturity in five years since 2003 and long-term KTB with a maturity in ten years have been traded since February 2008.

KTB with maturities in three and five years had a coupon rate of $8 \%$ as registered bonds and the government bonds were not received or cleared on the actual maturity dates. Instead, cash was paid to cover a price difference. LKTB with a maturity in ten years adopted physical delivery settlement in which bonds with a coupon rate of $5 \%$ with the time-to-maturity less than five years and six months were paid by real products. However, the final payment process has been simplified since October 25, 2010 so as to relive a burden for investors to take over the original bonds. So, it was switched to the cash payment method. Since the trade volume of KTB with a maturity in five years so insignificant, so it is expected to be delisted. The daily trade volume of KTB with a maturity in three years is fifty thousand contracts along with one hundred thousand contracts for open interest. 
Foreigners' investment on KTB vigorously began in 2002 and has continuously increased. So, one hundred sixty thousand open interest contracts were recorded in February, 2013. Foreigners' investment on Korean bonds became activated in 2007 after the global crisis represented by the bankruptcy of Lehman Brothers. The amount of bonds retained by foreigners which was 5 trillion won in 2006 was expanded to 102.9 trillion won. Foreign investors' influence in the Korean bond market has increased through various channels. Since the global financial crisis, strong quantitative easing policy has been implemented by US. It has played a role of a critical variable in the monetary policies of major countries. In this regard, a phenomenon of synchronized the US and Korean bond rates was observed in Korea. So, a series of studies on rate precedence have been followed. However, various maturity types as well as maturity discordance issues between Korean rates and overseas rates hampers analysis.

On the other hand, data on prices including the market values and closing prices are open to the public in the futures market where futures with the same maturity are traded so apparently it would be possible to implement more efficient metric analysis than the bond spot market. The study was processed based on the academic necessity on the effects of US treasury bond market on KTB futures market.

\subsection{Purposes of the Study}

Although a series of studies on the effects of US bond market on Korean counterpart has been followed; however, there are few studies on futures markets. So, the study carries significance in this regard. More objective and efficient analysis was achieved by using the publicly released data on 10 year treasury futures indices in both countries. The study aimed to contribute to establishing strategy for hedge trading and spot and futures trading in managing Korean bonds by analyzing effects of daily volatility and direction of US treasury futures index on the market values of Korean counterpart on the next day.

\subsection{Research Analysis Methodology}

The study analyzed volatility transfer effects from US treasury bond market to KTB futures market. For that, the study used daily data of US and Korean 10 year future indices. As an analysis method, GARGH(Generalized Autoregressive Conditional Heteroskedastic) which is used to analyze recent volatilities was used. An analysis was carried out to find out presence of volatility transfer effects from US 10 year treasury futures index to Korean counterpart (Sample period: November 1, 2011 through July 31, 2015).

\section{Literature Review and Theoretical Background}

\subsection{Literature Review}

Studies on effects of US bond yields on Korean one have been implanted from various angles. Lee (2001) argued that influence of US interest rate expanded after the financial crisis based on his dynamic interoperability analysis on Korean and US interest rates. Hong and Moon (2004) asserted that Korean interest rate is strongly influenced by US one after the market price evaluation on bonds due to price volatility transfer effects of Korean bond spot market and US counterpart. Lim and Seo (2010) suggested that concurred interest rates are fundamentally closely related to macro-economy.

A series of studies on foreigners' investment on spot and futures has been followed. Pak (2006) pointed that a low level of foreigners' investment on the bonds was caused by regulations posed by the Korean Government. Yang and Lee (2008) suggested that expansion of foreigners' investment in Korean bonds was due to arbitrage. Won and Joo (2009) argued that surging investment of foreigners to Korean bonds affected the Korean bond market. Kim and Lee (2010) illustrated that swap spread, national risks and international liquidity crises mainly affect on investment behaviors of foreigners towards Korean bond market. Pak (2014) asserted that foreigners' investment on bonds from 2010 reflect various factors (maturities, countries, risks and currency exchange rates) and foreigners' investment on treasury futures takes a role of major variable deciding directions of the interest rate.

Looking at extant studies on the price discovery functions and information transfer effects, Nam and Yun (2001) used GARCH to analyze the volatility transfer effects from US stock market to Korean counterpart. Yun found positive volatility transfer effects from 1999 to 2000. Lee (2012) adopted GARCH model to analyze information transfer effects between day and night futures markets of KOSPI 200, concluding that the night market yield is immediately reflected in the market values determined at the opening of the day market on the following day. Choi (2015) suggested in his study on the effects of the nighttime index options connected with EUREX on KRX stock index options market analyzing a period of August 2010 through July 2014 that information on the closing prices of call and put options was transferred to the market values of the regular market. 


\subsection{Understanding on KTB Treasury Futures}

10 year treasury futures refers to contracts to trade10-year government bonds with a residual period of 10 years based on the maturity date. The government bonds refers to bonds issued by the government and they are traded in the curb markets like securities firms as well as the circulation market like the head office of the security market.

\subsection{Summary of Korean Treasury Futures Index}

10 year treasury futures index also known as F-LKTB is an index calculated from prices of recently listed products in the KRX 10 year treasury futures market. The index is used to track the inverse ETD of 10 year treasury futures. F-LKTB based on 1,000p on January 3, 2011 has been published since October 24, 2011.

\subsection{Summary of US treasury Futures Index}

US treasury futures index of CBOT is a standardized trading agreement guaranteeing handing over mid-term or long-term bonds of the US Government. The concerned agreement is stipulated in the rules and regulations of CBOT which applies to it.

\section{Empirical Analysis}

In this chapter, GARCH model generalizing ARCH model was adopted to make a model of a conditional heteroscedastic time series which takes into account excess kurtosis and volatility with evidence of fat tails. The reason of adopting GARCH model instead of ARCH model is that GARCH model can bring effects similar to ARCH model of long linearity despite its few number of parameters. Moreover, variations of general financial time series show a tendency of continuity. Generally speaking, it is known that simple GARCH(1.1) model is enough for modeling.

\subsection{Data Collection and Basic Statistics}

In order to verify the information transfer effects of US 10 year treasury futures on Korean counterpart, daily data on US and Korean 10 year treasury futures for a period of November 1, 2011 through July 31, 2015 provided by CHECK was used.

Table 1. Basic statistics

\begin{tabular}{lcc}
\hline SORT & KTB & USB \\
\hline Mean & -0.000169 & $3.42 \mathrm{E}-07$ \\
Median & -0.000166 & 0.00012 \\
Maximum & 0.016914 & 0.00955 \\
Minimum & -0.008894 & -0.014202 \\
Std. Dev. & 0.00202 & 0.003053 \\
Skewness & 0.822986 & -0.445806 \\
Kurtosis & 11.62345 & 4.31291 \\
Observations & 928 & 928 \\
\hline
\end{tabular}

Note. KTB: 10 year Korean Treasury Futures Index, USB: 10 year US Treasury Futures Index.

\subsection{Empirical Effects}

1) Yield rate analysis on Korean treasury futures market

Above all ARMA(1.1)-GARCH(1.1) model was used as below to calculate the yield rate $\left(K T B_{t}\right)$ compared to the closing prices on the previous days of Korean treasury futures market in order to analyze information transfer effects of US 10 year treasury futures on Korean 10 year treasury futures.

$$
\begin{gathered}
R_{t}=\alpha+\beta R_{t-1}+\gamma \varepsilon_{t-1}+\varepsilon_{t} \\
h_{t}=a+b h_{t-1}+c \varepsilon_{t-1}^{2}
\end{gathered}
$$

In this case, $R_{t}$ is rate of return at time $\mathrm{t}, \mathrm{h}$ refers to conditional variance of the changing rates referred $\mathrm{R}$.

Below Table 2 is the ARMA(1.1)-GARCH(1.1) model on the yield rates of Korean 10 year treasury index compared to the closing prices of the previous days $\left(K T B_{t}\right)$. 
Table 2. Estimates of ARMA(1.1)-GARCH(1.1) model on the yield rates of Korean 10 year treasury index

\begin{tabular}{ccccccc}
\hline Sort & $\alpha$ & $\beta$ & $\gamma$ & $a$ & $b$ & $c$ \\
\hline \multirow{2}{*}{$K T B_{t}$} & -0.00015 & 0.630478 & -0.62447 & $2.62 \mathrm{e}-08$ & 0.926105 & 0.072027 \\
& $(0.0038)$ & $(0.004)$ & $(0.0048)$ & $(0.0161)$ & $(0.0000)$ & $(0.0000)$ \\
\hline
\end{tabular}

Note. $K T B_{t}$ : Yield rates of Korean 10 year treasury index compared to the closing prices of the previous days.

Parentheses refers to p-values.

In case of $K T B_{t}$ referring to yield rates of Korean 10 year treasury index compared to the closing prices of the previous days, AR coefficients of the mean equation were statistically significant at $1 \%$. Concerning conditional variances, $a$ referring the constant term was statistically significant at 5\% or lower while coefficients of $b$ and $c$ were statistically significant at $1 \%$ or lower. The value added from coefficients of the lagged error and the lagged conditional variance was lower than 1 so stationarity was found.

Below is the model for US 10 year treasury future index $\left(U S B_{t-1}\right)$.

$$
\begin{gathered}
R_{t}=\alpha+\beta R_{t-1}+\gamma \varepsilon_{t-1}+\varepsilon_{t}, \\
h_{t}=a+b h_{t-1}+c \varepsilon_{t-1}^{2}
\end{gathered}
$$

Below is Table 3 illustrating the ARMA(1.1)-GARCH(1.1) model on the yield rates of US 10 year treasury index $\left(U S B_{t-1}\right)$.

Table 3. Estimates from the ARMA(1.1)-GARCH(1.1) model on the yield rates of US 10 year treasury index $\left(U S B_{t-1}\right)$

\begin{tabular}{cccccc}
\hline Sort & $\beta$ & $\gamma$ & $a$ & $b$ & $c$ \\
\hline \multirow{U}{*}{$U_{S B_{t-1}}$} & 0.442123 & -0.47505 & $1.79 \mathrm{e}-07$ & 0.95437 & 0.026255 \\
& $(0.0926)$ & $(0.0654)$ & $(0.0681)$ & $(0.0000)$ & $(0.0019)$ \\
\hline
\end{tabular}

Note. $\left(U S B_{t-1}\right)$ : the yield rates of US 10 year treasury index.

Parentheses refers to p-values.

In case of $\left(U S B_{t-1}\right)$ referring to yield rates of US 10 year treasury index, AR coefficients of the mean equation were statistically significant at $10 \%$. Concerning conditional variances, $a$ referring the constant term was statistically significant at $10 \%$ or lower while coefficients of $b$ and $c$ were statistically significant at $1 \%$ or lower. The value added from coefficients of the lagged error and the lagged conditional variance was lower than 1 so stationarity was found.

2) Information transfer effects of US treasury futures index to Korean treasury futures market

The model was altered as below by adopting an exogenous variable to the conditional variance as a mean to analyze information transfer effects of US treasury futures to Korean treasury futures market.

$$
\begin{aligned}
& K T B_{t}=\alpha+\gamma U S B_{t-1}+\varepsilon_{t}, \\
& h_{t}=b h_{t-1}+c \varepsilon_{t-1}^{2}+f \varepsilon_{U S B t-1}^{2}
\end{aligned}
$$

As seen the model above, a substitute value for volatility was induced by residual sum of squares $\left(\varepsilon^{2}\right.$ USBt-1) referring to unexpected returns of US treasury futures market. The model was designed to find out what effects were brought by volatility shocks of US treasury futures to the yield rates of Korean treasury futures market. If $f$ value of the conditional variance is statistically significant, it means that volatility shocks of US treasury futures were transferred to Korean treasury futures market.

Table 4. Information transfer effects of US treasury futures index to Korean treasury futures market

\begin{tabular}{cccccc}
\hline Sort & $a$ & $\gamma$ & $b$ & $c$ & $f$ \\
Coef & -0.00013 & -0.35961 & 0.762061 & 0.131831 & 0.024799 \\
p-value & 0.0017 & 0.0000 & 0.0000 & 0.0000 & 0.0000 \\
\hline
\end{tabular}

According to verification results as seen in the Table 4, the coefficient $(f)$ of volatility of US treasury futures 
index yields as the exogenous variable was 0.024799 , statistically significant at $1 \%$ or lower. It was confirmed that information on the yield rates of US treasury futures index was transferred to Korean treasury futures index.

\section{Conclusion}

Despite extant research on effects of the US bond market on Korean bond market, rarely have the 10-year long-term products been studied. In particular, the study aimed to contribute to establishing trading strategy on spot and futures and hedge trading on Korean bond operation through analysis on the effects by using the long-terms future indices of the two countries. More objective and efficient analyses were implemented by analyzing effects of daily volatility and directions of US futures index on the market values of Korean futures index.

To find out volatility transfer effects to Korean bond futures market from US treasury futures market, daily data of US and Korean 10 year futures indices from November 1, 2011 to July 31, 2015 were used to analyze the presence of volatility effects by GARCH in which a residual sum of squares $\left(\varepsilon_{U S B t-1}^{2}\right)$ referring to unexpected returns of US treasury futures market was adopted. As a model to find out whether volatility shocks from US treasury futures to yields rates of Korean treasury futures market, statistically significant $f$ value of the conditional variance means that volatility shocks from US treasury futures market were transferred to Korean treasury futures index. Consequently, the coefficient $(f)$ of volatility of US treasury futures index yields as the exogenous variable which was 0.024799 , statistically significant at $1 \%$ or lower confirmed that information on the yield rates of US treasury futures index was transferred to Korean treasury futures index.

The study would contribute to establishing more rational and efficient strategy for investment and operation on bonds because investors can have important information regarding US treasury market that has influence on Korean bond futures market beforehand. In the future, further research is required to expand the study to other products like long-term bonds and a series of studies on short, medium and extra long-term products in accordance with market environments.

\section{References}

Antoniou, A., \& Holmes, P. (1995). Futures Trading, Infomation and Spot Price Volatility: Evidence for the FTSE-100 Stock Index Futures Contract Using GARCH. Journal of Banking and Finance, 19, 117-129. http://dx.doi.org/10.1016/0378-4266(94)00059-C

Barclay, M., \& Hendershott, T. (2008). A comparison of trading and non-trading mechanisms for price discovery. Journal of Empirical Finance, 15, 839-849. http://dx.doi.org/10.1016/j.jempfin.2008.03.001

Barclay, M. J., \& Hendershott, T. (2003). Price Discovery and Trading After Hours. Review of Financial Studies, 16(4), 1041-1073. http://dx.doi.org/10.1093/rfs/hhg030

Biais, B. P. H., \& Spatt, C. (1999). Price Discovery and Learning during the Preopening Period in the Paris Bourse. Journal of Political Economy, 107(6), 1218-1248. http://dx.doi.org/10.1086/250095

Cao, C., Ghysels, E., \& Hatheway, F. (2000). Price Discovery without Trading: Evidence from the Nasdaq Pre-opening. Journal of Finance, 55, 1339-1365. http://dx.doi.org/10.1111/0022-1082.00249

Choi, W. (2015). The Study on the Effects of the Nighttime Index Options connected with EUREX on KRX Stock Index Options Market. PhD dissertation at Business Administration Graduate School of Korea Aerospace University.

Corrado, C. J., \& Miller, T. W. (2005). The Forecast Quality of CBOE Implied Volatility Indexes. Journal of Futures Markets, 25(4), 339-373. http://dx.doi.org/10.1002/fut.20148

Engle, R. F. (1982). Autoregressive Conditional Heteroskedasticity with Estimates of the Variance of U.K. Inflation. Econometrica, 50, 987-1008. http://dx.doi.org/10.2307/1912773

Grammatikos, T., \& Saunders, A. (1983). Stability and the Hedging Performance of Foreign Currency Futures. Journal of Futures Markets, 3(3), 295-305. http://dx.doi.org/10.1002/fut.3990030305

Harvey, C. R., \& Whaley, R. (1992). Market volatility prediction and the efficiency of the S\&P 100 index option market. Journal of Financial Economics, 31(1), 43-73. http://dx.doi.org/10.1016/0304-405X(92)90011-L

Hill, J., Balasubramanian, V., Gregory, K., \& Tierens, I. (2006). Finding Alphavia Covered Index Writing. Financial Analysts Journal, 62(5), 29-46. http://dx.doi.org/10.2469/faj.v62.n5.4281

Chung-Hyo, H., \& Gyu-Hyun, M. (2004). The Price-discovery of Korean Bond Markets by US Treasury Bond Markets. The Korean Journal of Financial Management, 21(2), 125-151. 
Junghan, K., \& Daegi, L. (2010). Determinants for foreigners' investment in Korean Bond Markets. Korea Institute of Finance.

Woo-Baik, L. (2012). Information Transmission between Nighttime Trading and Daytime Trading: Evidence from KOSPI 200 Futures. Korean Journal of Futures and Options, 20(1), 101-131.

Yeonho, L. (2001). Capital Market Consolidation and Dynamic Interlocking of Korean Interest Rate with US. Japanese and European counterparts. Finance Research, 15(2), Korea Institute of Finance.

Jin, L., \& Gyeong, S. (2010). Path Analysis on Synchronizing Policies on Finance. Institute of Finance \& Economy Research at Bank of Korea. Finance \& Economy Research, 420.

Madhavan, A., \& Panchapagesan, V. (2000). Price Discovery in Auction Markets: A Look inside the Black Box. Review of Financial Studies, 13(3), 627-658. http://dx.doi.org/10.1093/rfs/13.3.627

McKenzie, M. D., Brailsford, T. J., \& Faff, R. W. (2001). New Insight into the Impact of the Introduction of Futures Trading on Stock Price Volatility. Journal of Futures Market, 21, 237-255. http://dx.doi.org/10.1002/1096-9934(200103)21:3<237::AID-FUT3>3.0.CO;2-0

Menachem, B., \& Marti, G. S. (1988). A Simple Formula to Compute the Implied Standard Deviation. Financial Analysts Journal, 44(5), 80-83. http://dx.doi.org/10.2469/faj.v44.n5.80

Nam, J., \& Kihyang, Y. (2001). Analysis on the Volatility Transfer Effects of US Stock Market to Korean Counterpart. Joint Academic Conference of Korea Finance Academic Association.

Daegeun, P. (2006). Determinants of Cross-border Bond Investment. Finance Academic Association, 11(2).

Jongyeon, P. (2014). Determinants for Foreigners' Investment on Spot and Futures and their Impacts. PhD dissertation at Chungang University.

Seungyeon, W., \& Sangyoung, J. (2009). A Study on the Determinants of Foreigners' Domestic Bond Investment and Their Impacts on the Korean Bond Market. Economics Research, 57(3).

Yanghyun, Y., \& Haerim, L. (2008). Analysis on Arbitrage Induction and Foreign Banks and Foreigners' Investment on Korean Bond. Research Statistics of Monthly Release by Bank of Korea.

\section{Copyrights}

Copyright for this article is retained by the author(s), with first publication rights granted to the journal.

This is an open-access article distributed under the terms and conditions of the Creative Commons Attribution license (http://creativecommons.org/licenses/by/3.0/). 